\title{
4 RELATING FINDINGS TO NEIGHBOURHOOD AND URBAN POLICIES
}

\subsection{Implications for neighbourhood initiatives}

\subsubsection{Amsterdam: Balancing active citizenship, inclusivity, and sustainability}

Initially, the selected initiatives were clustered according to whether they were organised 'top-down' or 'bottom-up'. During the fieldwork, we found that these distinctions are not always clear-cut and therefore decided to include 'hybrid' as an additional category. All selected initiatives receive (sometimes significant) funding from either housing associations or local government, often from both. None of the initiatives would be able to continue without this funding. In fact, one initiative - the Vrouwenbazaar - lost its premises as a result of changes in the municipal's real estate policy and now uses a neighbourhood centre together with other neighbourhood groups. Another initiative - De Hardreiking - was on the brink of losing its funding, which would have spelt the end of this initiative. Even those initiatives initially characterised as 'resident-driven' (bottom-up) are therefore very much embedded in institutional structures.

Furthermore, some resident-driven initiatives are more bottom-up in theory than in practice. Especially the neighbourhood centre De Handreiking (whose philosophy includes that residents design and execute activities) had trouble finding residents that can take on organisational roles. This might be due to the centre's relative newness, as in two other centres which employ the same philosophy this works better. In some other initiatives too, a lot of the organisational work is done by professionals or 'professional residents' (notably students involved in the VoorUit project and full-time volunteers in other projects).

De Handreiking, as well as VoorUit and the three neighbourhood living rooms, are subsidised by housing associations. As such, they have to submit detailed records of activities organised, participants, etc. This is particularly burdensome for De Handreiking, which is supported by three different housing associations. Its employees spend a lot of time taking attendance (including name, address, and date of birth of all participants during every activity) and making reports, leaving limited time to engage with participants.

Summing up, all of the initiatives studied in the Amsterdam neighbourhoods can be classified as hybrid in the sense that they are dependent on financial support from public institutions for their survival, but operate according to the principle that residents themselves should design and carry out activities. 'True' bottom-up initiatives are rare, as all initiatives eventually become embedded in institutional structures. On the other hand, this means that all initiatives (also) offer room for residents to not only participate 
but also to become involved more actively, and therefore offer them the opportunity to realise their plans for the neighbourhood. In the studied initiatives, dependence on short-term subsidies created insecurity as the continued existence of the initiative is uncertain and in some cases (interethnic) neighbourhood relations deteriorated due to competition for funding. Furthermore, the requirement that initiatives are not only for, but also by, residents is not always realistic given a general lack of organisational capital and its unequal distribution in the neighbourhoods that need these initiatives the most. While there is currently a mix of active residents across social class (although 'native' Dutch are overrepresented), a too strong emphasis on 'active citizenship', which presumes a significant degree of independence and know-how from the side of volunteers, might tip the scales towards favouring activities by middle-class 'native' Dutch residents while inhibiting participation of residents of migrant background and working-class 'native' Dutch.

\section{ZUSAMMENFASSUNG:}

Zusammenfassend können alle in Amsterdam untersuchten Initiativen als hybrid klassifiziert werden, da sie einerseits von öffentlichen Geldern abhängig sind, andererseits aber nach dem Prinzip funktionieren, dass die BewohnerInnen die Aktivitäten konzipieren und gestalten. „Echte“ Bottom-up-Initiativen sind selten, da alle Initiativen in institutionelle Strukturen eingebettet sind. Andererseits bieten alle Projekte Freiräume für BewohnerInnen nicht nur teilzunehmen, sondern sich auch aktiver einzubringen und hiermit auch eigene Pläne zur Entwicklung des Wohnumfelds zu realisieren. In allen Initiativen schafft die Abhängigkeit von kurzfristigen Subventionen Unsicherheit, da die längerfristige Durchführbarkeit der Projekte stets ungewiss ist. Auch die Voraussetzung, dass Initiativen nicht nur für die BewohnerInnen da sind, sondern auch von diesen gestaltet werden sollen, ist nicht selten unrealistisch angesichts des Mangels an Organisationskapital und dessen ungleicher Verteilung zwischen den einzelnen Stadtvierteln. Während ein Gemisch von aktiven BewohnerInnen quer durch alle sozialen Schichten (mit Überrepräsentation der ethnischen Niederländer) festzustellen ist, besteht ein zu starkes Gewicht auf der ,, aktiven Bürgerbeteiligung “, die einen hohen Grad an Unabhängigkeit und Knowhow voraussetzt, was die Beteiligung ethnisch nicht niederländischer Bewohner oder auch von ArbeiterInnen erschwert.

\section{SAMENVATTING:}

Samenvattend kunnen we met betrekking tot de Amsterdamse buurtinitiatieven stellen dat zij allemaal een hybride organisatiestructuur kennen, aangezien ze voor hun voortbestaan afhankelijk zijn van publieke middelen maar in hun werkwijze uitgaan van het principe dat bewoners zelf activiteiten moeten bedenken en uitvoeren. ,Echte“ bottom-up initiatieven zijn dan ook zeldzaam, aangezien bijna alle initiatieven vroeg of laat worden opgenomen in institutionele structuren. Dit betekent echter ook dat alle 
onderzochte initiatieven bewoners de ruimte bieden om niet alleen te participeren maar ook meer actief betrokken te worden. Bewoners krijgen hierdoor de kans om hun eigen plannen voor de buurt te realiseren. Een groot nadeel van de onderzochte initiatieven is hun afhankelijkheid van korte-termijn subsidies (vaak voor één jaar) waardoor vaak lang onduidelijk is of het initiatief doorgang kan vinden. Daarnaast ontstaat er soms competititie over subsidie tussen verschillende buurtinitiatieven, wat de sfeer in de buurt niet ten goede komt. Het actief betrekken van bewoners is niet altijd realistisch gegeven de vaak ambitieuze doelstellingen van de initiatieven en het ontbreken van organisatorisch talent of ,knowhow' onder bewoners, juist in de buurten die dit het hardste nodig hebben. Momenteel vonden we nog een mix van actieve bewoners van verschillende etnische groepen en sociaaleconomische achtergrond, maar het gevaar dreigt dat wanneer te zwaar wordt ingezet op de kennis en kunde van vrijwilligers dit de participatie van bewoners met een lagere opleiding en/of migratie-achtergrond belemmert.

\subsubsection{Vienna: Creating integration and preventing exclusion}

Integration initiatives - independent of whether they are at the city or neighbourhood level - by definition aim to increase integration during and after participation in the initiative. Our analysis shows, however, that unintended exclusionary mechanisms (see Figure 1) can lead to the exclusion of often hard-to-reach groups.

Figure 1: Initiatives' risks of exclusion

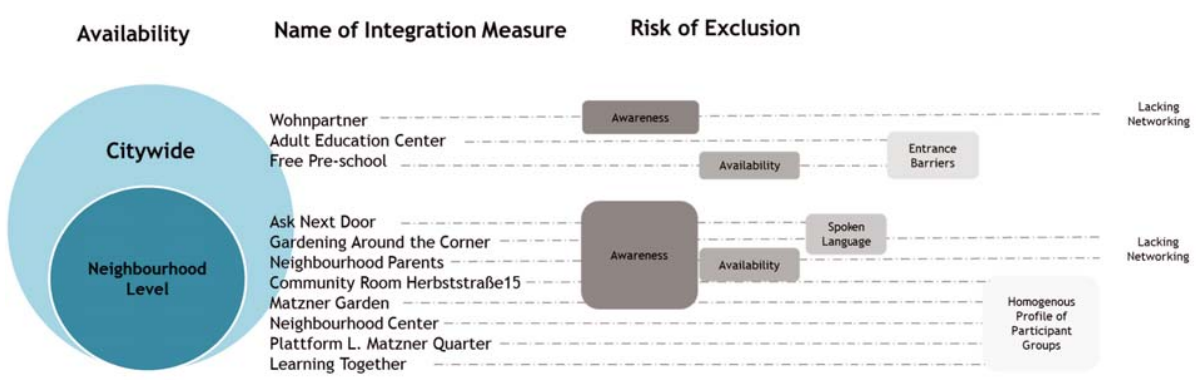

Source: Own production by ICEC research team, 2016.

These exclusionary mechanisms concern the publicity and the availability of initiatives, the language primarily spoken or other entry barriers, such as fees. The study also shows that too much homogeneity in participant groups can have an exclusionary effect on individuals who do not identify as a member of the dominant group within the context of the initiative (e.g. clothing, ethnic background, age, gender). 
In addition, internal and external networking is required in order to embed integration initiatives into existing, more long-term policy structures.

The implications for citywide measures that are all organised in a top-down manner relate mostly to awareness and barriers to participation. While the Adult Education Centre and free pre-school are well-known, their formal requirements (e.g. fees, employment status) cause severe exclusionary effects, especially amongst nonAustrian social groups. Although the inner-institutional perception (the stakeholders' view) is that the target group is mostly convinced of the benefits of their initiative, the external perception by (non-)participants shows a more nuanced opinion on the effectiveness of awareness campaigns. Top-down measures especially benefit from word-of-mouth recommendations within specific ethnic communities. As a result, our analysis supports the recommendation of activating gate-openers (e.g. well-connected mothers) to reach out to hard-to-reach communities.

As for the neighbourhood-wide measures, these are mostly organised in a bottom-up or hybrid manner and often lack more (multilingual) awareness campaigns as well as a profound understanding of the "actual inter-ethnicity" in the initiative. As access to hard-to-reach groups is mostly perceived as a first success, critical reflection on the heterogeneity within multi-ethnic groups is lacking. As the analysis shows, it is an ongoing task by initiators to promote not only inclusion and interaction of different ethnic groups, but also different social groups and to stimulate interethnic contacts next to intra-ethnic socialising. As such, we highly recommend some sort of regular assessment - as a preliminary form of systemised monitoring - to create a valid source for decision-making processes with regard to the design and success of initiatives. A better understanding of the "diversification within ethnic heterogeneity" may also help initiators to report in a more concise and persuasive manner to funding parties (e.g. district or city government).

\section{ZUSAMMENFASSUNG:}

Bezüglich der sich auf die Gesamtstadt beziehenden Initiativen, die alle dem Topdown-Typus zuzuordnen sind, bestehen in Wien vor allem die Probleme der Bekanntheit und der Zutrittsbarrieren. Abgesehen von den positiven Effekten multilingualer Strategien der Öffentlichkeitsarbeit profitieren Top-down-Initiativen besonders auch von Mund-zu-Mund-Propaganda innerhalb der jeweiligen ethnischen Communities. Als Ergebnis dieser Studie empfehlen wir die Aktivierung von Schlüsselpersonen, um auch schwieriger erreichbare Gruppen gezielter anzusprechen. Bei den Initiativen mit lokalem Bezug gilt, dass diese meist bottom-up oder hybrid organisiert sind und mehrsprachige Öffentlichkeitsarbeit häufig nicht betreiben. Unsere Analyse zeigte, dass die InitiatorInnen es als eine ihrer wichtigen Aufgaben ansehen, die Inklusion und Interaktionen unterschiedlicher ethnischer und sozialer Gruppen zu fördern. In diesem Zusammenhang empfehlen wir dringend eine Art regelmäßiges Assessment als Vorstufe 
$z u$ einem systematischen Monitoring und als Grundlage für Entscheidungsprozesse hinsichtlich der Konzeption und des Erfolgs der Initiativen. Ein fundierteres Verständnis der „Diversifikation innerhalb ethnischer Heterogenität“ kann InitiatorInnen helfen, möglichen Finanziers überzeugender gegenüberzutreten.

\section{SAMENVATTING:}

Uitsluitende mechanismen binnen de Weense initiatieven bestaan vooral uit een gebrek aan kennis over wat er in de buurt wordt georganiseerd, taalbarrières en andere barrières zoals geldelijke bijdragen. Bij top-down initiatieven is het van belang dat goed wordt gekeken naar of de ingangseisen bepaalde groepen bewoners onterecht uitsluiten. Daarnaast kan gebruik worden gemaakt van, gatekeepers ' die lastig te bereiken groepen kunnen activeren en stimuleren om deel te nemen. Bij hybride en bottom-up initiatieven is er vaak een gebrekkige bewustwording over hoe men het initiatief toegankelijker kan maken. Daarnaast ontbreekt regelmatig een kritische houding ten opzichte van wie men wil bereiken en waarom, en is er onvoldoende oog voor diversiteit binnen etnische groepen. Regelmatig monitoneren en rapporteren blijft daarom nodig - en kann ook dienen als argumentatie voor de positieve werking van het initiatief tegenover subsidiepartijen.

\subsection{Implications for urban policies}

Based on the empirical findings as well as the theoretical discussion, we suggest that interethnic coexistence can be regarded as the 'middle' of a continuum. If we conceptualise coexistence as the pillar of a see-saw, we can identify what could be a negative or a positive deviation from coexistence (see Figure 2). If peaceful coexistence - living side-by-side - is not maintained, this will potentially lead to conflicts and disconnection from the neighbourhood. If, in contrast, coexistence is promoted and strengthened, this may result in neighbourhood belonging.

Figure 2: The see-saw: Coexistence as the middle of a continuum

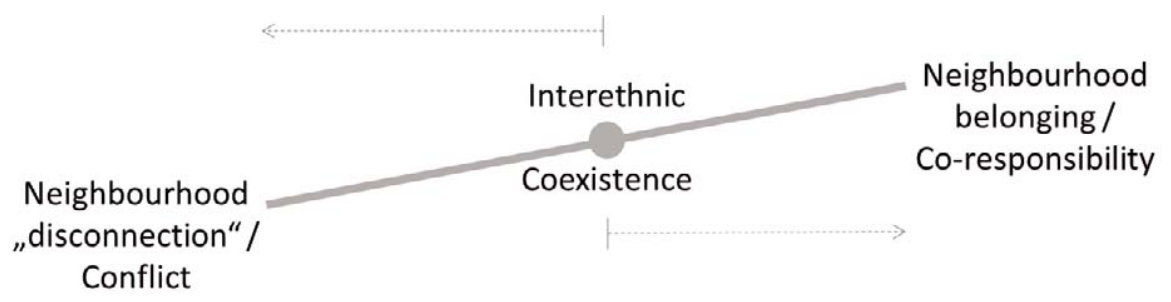

Source: Own production by ICEC research team, 2015 
Our analysis clearly indicates the importance of investment in neighbourhood belonging from the side of policymakers and public stakeholders. Peaceful coexistence is not simply a happy accident that occurs without any effort and investment in local integration initiatives (see Figure 3). Rather, this stability - and a potential shift to the 'right side of the see-saw' - requires long-term commitment from policymakers, in particular:

- Continuous support of local initiatives and provision of neighbourhood spaces

- Regular monitoring of inclusionary and exclusionary (side-)effects of existing initiatives

- Outreach activities to gatekeepers of hard-to-reach communities

- Acknowledging that neighbourhood belonging is a process that needs time, but continue to offer opportunities to become engaged in the neighbourhood.

If policymakers understand interethnic coexistence as a peaceful condition in the neighbourhood that enables neighbourhood belonging, they will also be successful in communicating that belonging requires two prerequisites: a political and societal environment that allows neighbourhood belonging to develop for all residents, and a community that actively connects to its neighbourhood and gives something back to, and as, co-responsible residents.

Figure 3: Prerequisites and added value of different levels of inclusion

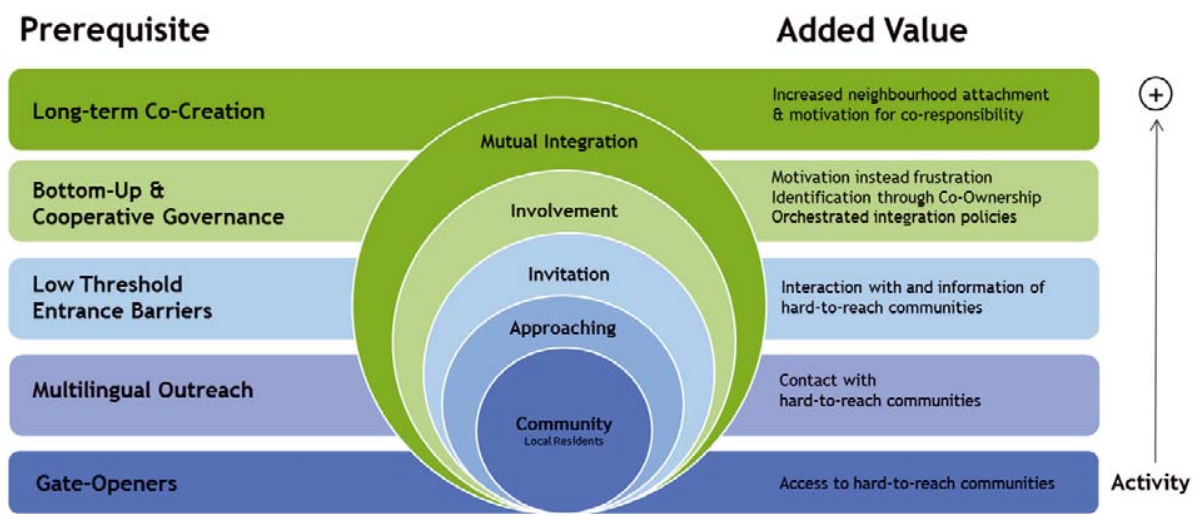

Source: own production by ICEC research team, 2016 
Figure 4: Interethnic coexistence in European cities

HOW CAN

\section{INTERETHNIC \\ CO-EXISTENCE \\ WORK IN SUPERDIVERSE \\ NEIGHBOURHOODS?}

Interethnic Co-existence in

European Cities (ICEC)

This project is based on a systematic comparison Our analysis suggests that in contrast to top-

of the aims, structural features and outcomes down initiatives, participation in bottom-up

of integrative initiatives at the neighbourhood or hybrid initiatives generally correlates to

level in Amsterdam, Vienna and Stockholm. neighbourhood belonging. Interethnic co-

We access and exachange examples of good existence is a long-term process based on

practice between the three distinct European the activities of the actors and networks

cities. Results can be used and implemented involved. Peaceful co-existence requires

in municipal policies and bottom-up initiatives local integration initiatives and long-term

aimed at creating integrative neighbourhoods. commitment from policymakers. 


\section{INTERETHNIC CO-EXISTENCE}

Investing in neighbourhood belonging from the side of policymakers and public stakeholders is of crucial importance. Peaceful co-

existence is not simply a happy accident that occurs without effort

in the form of local integration initiatives. Rather, this stability - and

a potential shift to the 'right side of the see-saw' - requires long-

term commitment from policymakers, in particular:

- Continuous support of local initiatives and provision

of neighbourhood spaces

- Regular monitoring of inclusionary and exclusionary

(side-)effects of existing initiatives

- Outreach activities to community gatekeepers of

hard-to-reach groups

- Acknowledging that neighbourhood belonging

is a process that needs time, but can offer

opportunities for people to become engaged

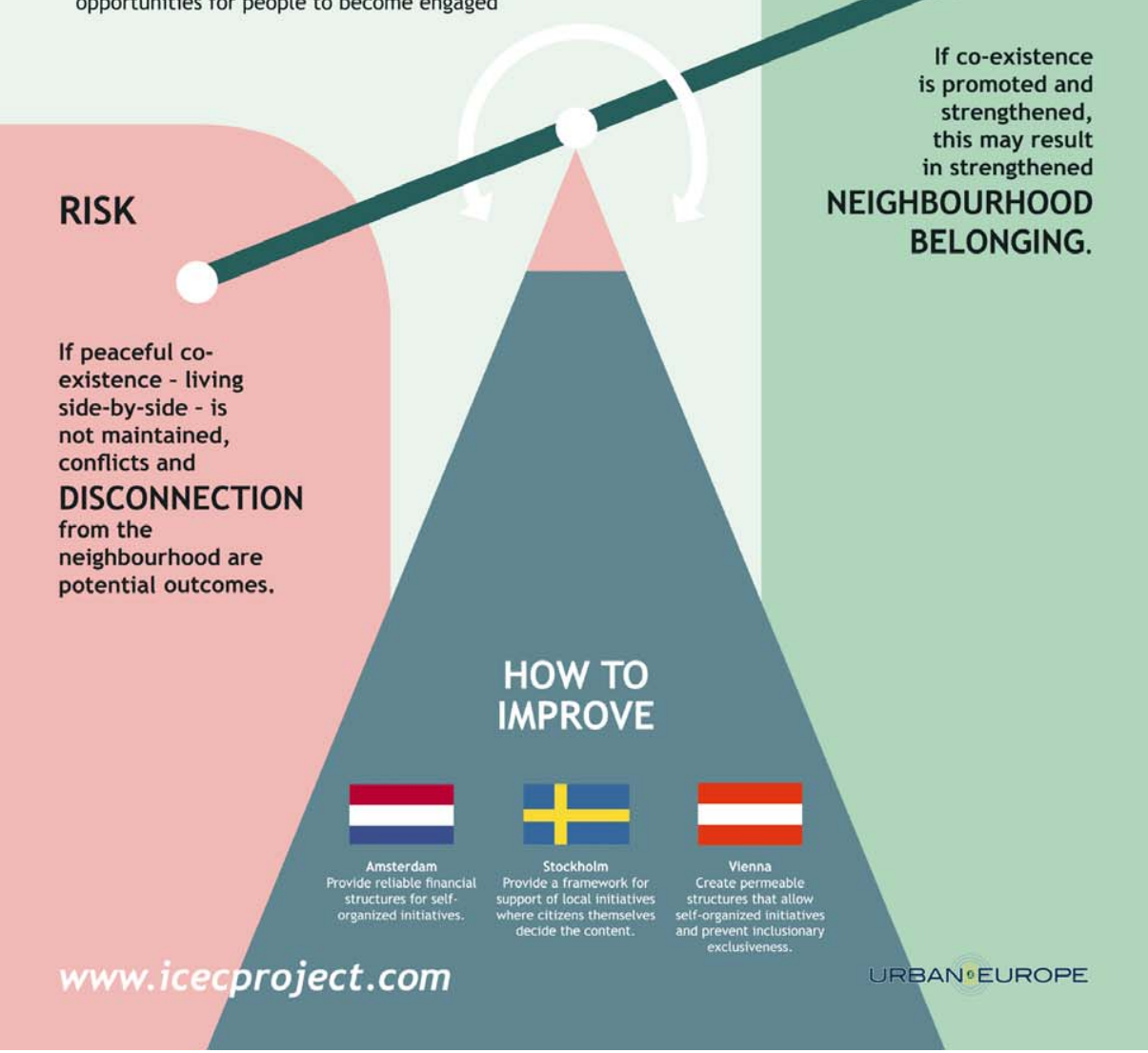


Figure 5: Interethnisch samenleven in Europese steden

\section{HOE KUNNEN WE}

INTERETNISCH

SAMENLEVEN

IN SUPERDIVERSE

BUURTEN LATEN

WERKEN?

Interetnisch samenleven in

Europese steden (ICEC)

Dit project (2013-2017) is gebaseerd op een

systematische vergelijking van de doelen,

eigenschappen en uitkomsten van integratie-

initiatieven op buurtniveau in Amsterdam,

Wenen en Stockholm. We zoeken voorbeelden

van 'goede praktijken' en wisselen deze uit

tussen de drie verschillende Europese steden.

De resultaten kunnen worden gebruikt in

gemeentelijk beleid en 'bottom-up' initiatieven

gericht op het creëren van geïntegreerde

buurten.
Onze analyse suggereert dat - in tegenstelling

tot 'top-down' initiatieven - participatie in

'bottom-up' of hybride initiatieven samen gaat

met je thuis voelen in de buurt. Interetnisch

samenleven is een proces van de lange termijn

dat voortbouwt op de activiteiten van de

betrokken actoren en netwerken. Vreedzaam

samenleven vereist beleidsmakers die langdurig

betrokken zijn bij lokale integratie-initiatieven. 


\section{INTERETNISCH

SAMENLEVEN

Investeren in thuisgevoel in de buurt door beleidsmakers en

maatschappelijke partijen is van cruciaal belang. Vreedzaam samenleven

is geen gelukkig toeval dat plaatsvindt zonder inspanningen in de vorm van

lokale integratie-initiatieven. In tegendeel, deze toestand van stabiliteit

- en een mogelijke beweging naar de rechterkant van de wip - vereist

langdurige betrokkenheid van beleidsmakers, met name:

- Voortdurende steun voor lokale initiatieven en voorzien

in publieke ruimtes in de buurt.

- Regelmatig monitoren van de insluitende en uitsluitende

(bij)effecten van bestaande initiatieven.

- Outreach activiteiten om sleutelfiguren in moeilijk te

bereiken gemeenschappen te betrekken.

- Erkennen dat zich thuis voelen in de buurt een proces

is dat tijd vergt, maar mogelijkheden blijven aanbieden

om betrokken te raken bij de buurt.

POTENTIEEL \& VERANDERING

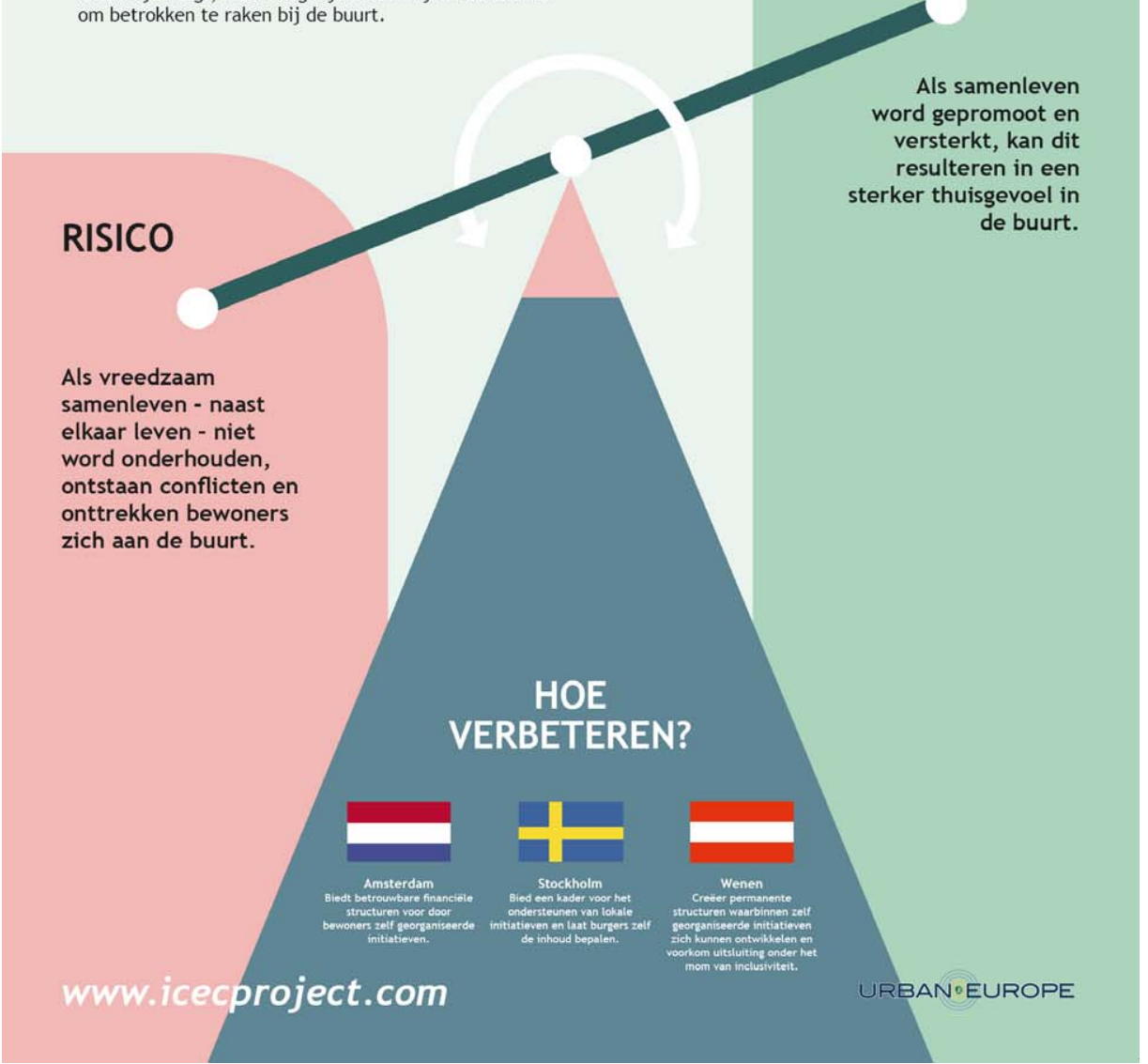


Figure 6: Interetnisk samexistens i Europeiska städer

\section{HUR KAN \\ INTERETNISK \\ SAMEXISTENS \\ FUNGERA I \\ MÅNGKULTURELLA \\ BOSTADSOMRÅDEN?}

INTERETNISK SAMEXISTENS I

EUROPEISKA STÄDER (ICEC)

Projektet bygger pả en systematisk jämförelse Vår analys tyder pá att i motsats till top-down-

mellan mål, strukturella egenskaper och resultat initiativ korrelerar deltagandet $\mathrm{i}$ bottom-up

av initiativ och insatser för sammanhållning eller hybrid-initiativ $i$ allmänhet till vi-känsla $i$

och vi-känsla i bostadsområden i Amsterdam, bostadsomrádet. Interetnisk samexistens är en

Wien och Stockholm. Arbetet går ut på att lảngsiktig process baserad pả berörda aktörers

tillgängliggöra och utbyta erfarenheter mellan aktiviteter och involverade nätverk. En väl

de tre europeiska städerna utifrản exempel fungerande samexistens kräver lokala initiativ

på god praxis. Resultaten kan användas och och långsiktigt engagemang från beslutsfattare.

implementeras i kommunala riktlinjer och lokala

initiativ som syftar till att skapa integrerade

bostadsområden. 


\section{INTERETNISK \\ SAMEXISTENS}

Att beslutsfattare och offentliga intressenter investerar $i$ vi-känsla

$i$ bostadsområden är av avgörande betydelse. En väl fungerande

samexistens är inte bara en lycklig tillfällighet som sker utan

ansträngning i form av lokala initiativ. Snarare kräver denna

stabilitet - och ett potentiellt skift till "gungbrädans högra sida“ -

långsiktigt engagemang från beslutsfattare, i synnerhet:

- hållbart stöd till lokala initiativ och tillhandahållande av lokaler i

bostadsområden

- Regelbunden uppföljning och utvärdering av inkluderande och

uteslutande (sido-) effekter av befintliga initiativ

- Riktade aktiviteter till lokala eldsjälar som har kontakter och är

kända i grupper som är svåra att nå

- Acceptera att vi-känsla i bostadsområden är en process som behöver

tid, men kan erbjuda möjligheter för människor att bli engagerad

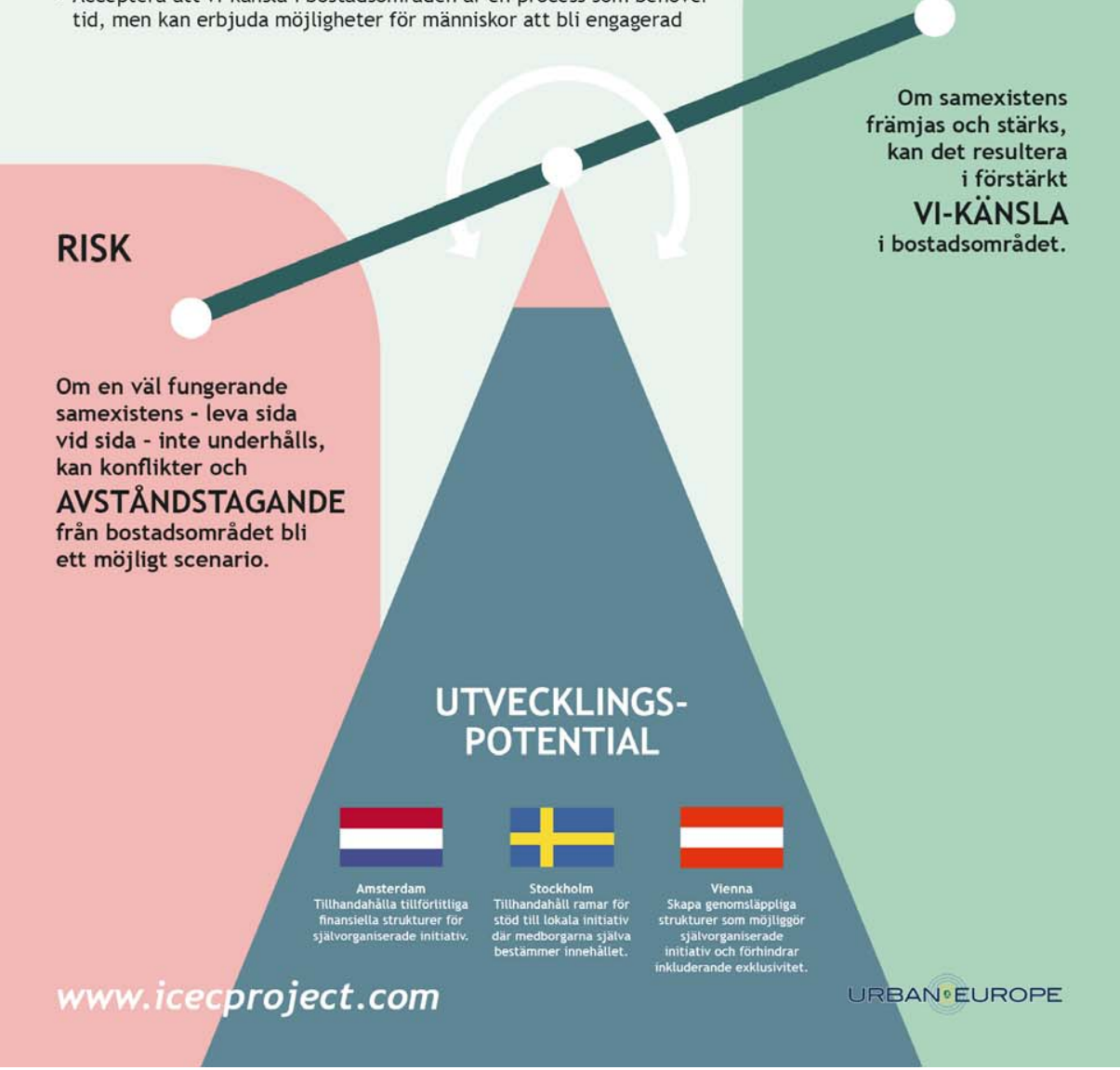


Figure 7: Interethnisches Zusammenleben in europäischen Städten

\section{WIE FUNKTIONIERT INTERETHNISCHES MITEINANDER IN SUPERDIVERSEN STADTTEILEN?}

Interethnisches Zusammenleben

in europäischen Städten (ICEC)

Dieses Forschungsprojekt (Laufzeit 2013-2017)

vergleicht Ziele, Mechanismen und Effekte

integrativ wirkender Stadtteilinitiativen in Amsterdam, Wien und Stockholm.

Interessante Praktiken werden bewertet

und Ergebnisse zwischen den drei euro-

päischen Städten ausgetauscht, um einen

gegenseitigen Lernprozess anzustoßen. Die

Forschungsergebnisse sind sowoht für die

Stadtteilpolitik als auch für Bottom-up-

Initiativen, die integrative Stadtteile als

Zielvorgabe formulieren, relevant.

www.icecproject.com
Der systematische Vergleich zeigt deutlich, dass die Teilnahme an sogenannten Bottom-

up- oder auch an hybriden Stadtteilinitiativen - im Vergleich zu Top-down-Initiativen - eine deutlichere Auswirkung auf die individuelle Stadtteilzugehörigkeit hat. Interethnisches Miteinander ist ein langfristiger Prozess, der sehr stark von den involvierten Akteurlnnen (Initiatorlnnen, TeilnehmerInnen, Fördergeberinnen etc.) und deren Netzwerken abhängig ist. Ein möglichst konfliktarmes Miteinander bedarf daher dringend lokaler Integrationsmaßnahmen, die von politischen EntscheidungsträgerInnen langfristig unterstützt werden. 


\section{INTERETHNISCHES MITEINANDER}

Eine besondere Wichtigkeit kommt hier politischen und öffentlichen

Entscheidungsträgerlnnen zu, die das individuelle Zugehörigkeitsgefühl zu einem Stadtteil fördern und unterstützen können. Denn ein konfliktfreies Miteinander ist keinesfalls selbstverständlich. Es stellt sich nicht ohne die Bemühungen lokale Integrationsmaßnahmen ein. Vielmehr benötigt ein stabiles nachbarschaftliches Miteinander langfristige Unterstützung von politischen EntscheidungsträgerInnen, um idealerweise eine Verlagerung zur Chancenseite der Wippe zu bewirken:

- Kontinuierliche Unterstützung von Stadtteilinitiativen und Versorgung mit entsprechend nutzbaren Stadtteilräumen

- Regelmäßiges Monitoring inkludierend oder exkludierend wirkender

(Neben-)Effekte von bestehenden Stadtteilinitiativen

- Aufsuchende Öffentlichkeitsarbeit, um Kontakte zu SchlüsselakteurInnen schwer erreichbarer Gruppen aufzubauen

- Generelle Anerkennung, dass es sich bei der Entwicklung von individuellen Gefühlen der Stadtteilzugehörigkeit um einen zeitintensiven Prozess handelt. Gleichzeitig bietet dieser Prozess auch die Möglichkeit, sich im Stadtteil aktiv zu engagieren.

POTENTIAL \& CHANCE
Ein stärkeres Gefühl individueller STADTTEIL-

ZUGEHÖRIGKEIT entsteht, wenn das nachbarschaftliche Miteinander durch öffentliche Akteurlnnen gefördert und gestärkt wird.

NACHBARSCHAFTSKONFLIKTE und ein persönliches Gefühl der STADTTEILENTFREMDUNG sind potentielle

Risiken, wenn das konfliktfreie Miteinander - auch im Sinne eines „NebeneinanderherLebens" - nicht unterstuitzt wird. 


\subsubsection{Amsterdam: About inclusivity, sociality and active residents}

The following details some considerations regarding the design of neighbourhood policies and their possible outcomes. These are not to be considered universal recommendations, instead, they point to aspects of how these policies work 'on the ground' in the studied neighbourhood initiatives and the implications for those working to create or maintain interethnic coexistence in diverse neighbourhoods.

Defining inclusivity: Consider why inclusiveness is important in a specific initiative or activity, and how it can be best achieved. For the current organisation of many initiatives, being inclusive means that everybody is welcome in principle, but in practice this often means that not all groups feel equally welcome or called on to participate. This was, for example, the case for those who would prefer to participate in same-gender settings, or in a language other than Dutch. In some cases, limited or selective inclusivity is more worthwhile, or the goal should be achieving side-by-side diversity rather than a complete mix.

'Thin' versus 'thick' sociality: Initiatives often do not generate strong social bonds where these did not exist before. However, they might still be successful in creating superficial encounters and sociality. Rather than friendships, encounters generated by initiatives more often consist of things like greeting one another on the street or engaging in small-talk. While these are perhaps seen as 'falling short' of more ambitious policy aims, these effects are appreciated by participants and contribute to a sense of belonging to the neighbourhood.

Supporting active residents: In order to have a sustainable and diverse 'participation infrastructure', (potential) active residents need institutional support that is durable (i.e. not project-based). Current projects have enthused many residents - both those who were already active and those who were not. Their efforts are integral to an initiative's success. However, participation requires energy and skills that are not always readily available to active residents. Many therefore state that they need more support (financial and otherwise) to continue in the future. This could include limited financial compensation or opportunities to professionalise or gain tangible skills. In addition, there should be a fair and realistic assessment of activities that should be paid as opposed unpaid work, and activities that are the responsibility of residents themselves rather than the municipality and/or housing associations.

Participation and wider neighbourhood relations: Residents cannot always reach a consensus on how neighbourhood budgets should be spent. Especially when the rules for subsidy allocations are unclear or there are budget cuts, existing communities and/or organisations can become competitors, which can be detrimental to social relations in the neighbourhood. Even though professionals strive to be as transparent as possible, for example regarding their criteria for financial support, this can still be a source of friction among residents who might have limited knowledge or experience of 
this kind of bureaucracy. In addition, residents do not always agree with professionals or with each other on what the neighbourhood - or part of it - needs.

Rethinking 'active citizenship': While many residents are happy to be given the chance to become involved in their neighbourhood, others are not able or willing to be active citizens. Initiatives should be mindful of different capacities and desires to participate among residents. For many residents, the neighbourhood is not a major place of attachment, and this is not necessarily problematic. These residents might be active in very different ways (in paid, voluntary, or informal work outside the neighbourhood). Moreover, for some residents involvement is not feasible due to other limitations, including illness, poverty, or care obligations. It is therefore important to be mindful of differing levels at which residents can be actively involved in the neighbourhood.

\section{ZUSAMMENFASSUNG:}

Die generellen Implikationen der Resultate der vorliegenden Studie für städtische Politiken wurden in Abbildung 2 veranschaulicht. Diese zeigt, dass interethnisches Zusammenleben als die Mitte eine Kontinuums angesehen werden kann. Darüber hinaus ist es auch relevant, stadtspezifische Vorschläge abzugeben, die sich nicht als universale Empfehlungen verstehen, aber auf Aspekte hinzuweisen, wie die Initiativen sich besser positionieren und effizienter funktionieren könnten. Die fünf wichtigsten, sich auf Amsterdam beziehenden Empfehlungen sind die Folgenden: Definieren von Inklusivität, distanzierte versus enge Sozialkontakte, Unterstützung für aktive BewohnerInnen, Partizipation und Einbindung in darüber hinausgehende Beziehungen im Wohnumfeld sowie ein Überdenken des Konzepts der Bürgerbeteiligung.

\section{SAMENVATTING:}

Afbeelding 2 toont de algemene implicaties van ons onderzoek voor stedelijk beleid. Interetnisch samenleven kan worden gezien als het midden van een continuum, hier voorgesteld als wip. Daarnaast zijn voor elke stedelijke context afzonderlijke aanbevelingen te maken waardoor initiatieven beter kunnen functioneren. In Amsterdam zijn de vijf belangrijkste aanbevelingen het kritisch bekijken van de noodzaak van inclusiviteit, het waarderen van meer oppervlakkige contacten, het ondersteunen van actieve bewoners, subsidievertrekking transparanter en minder competitief maken en het kritisch bekijken van dogma's met betrekking tot de participatiesamenleving en actief burgerschap. 


\subsubsection{Vienna: About compensation spaces and appreciation of the efforts of coexistence}

First, it should be noted that the urban neighbourhood itself might not always be the primary frame of reference, especially for younger and highly mobile residents. It is thus necessary to take into account spatial reference units and urban qualities beyond the neighbourhood.

Compensation spaces: Interviewees often make use of 'compensation spaces' (physically and socially) to overcome neighbourhood characteristics they are dissatisfied with, e.g., by visiting green spaces outside the neighbourhood or having a second home in the countryside. Our findings have shown that the socially relevant reference groups are often not the local communities, but the city more generally or in particular social networks spread across the city. Looking at intra-city mobility can also be informative for studying the relevance of the neighbourhood.

Effects of participation: In certain locally offered initiatives, effects of participation on an individual's neighbourhood attachment seem to be more moderate than originally expected. However, the findings confirm that participation does tend to reinforce social embeddedness. From a realistic point of view, policymakers cannot expect 'hyper-active' residents as a dominant type. Instead, it is vital that supportive conditions are facilitated to allow co-responsibly (bottom-up) organised initiatives. To better involve immigrants, this could include a stronger - target-group oriented and multi-lingual - information policy on the availability of services, support and grants as well as easier access to small grants.

Inclusivity versus exclusivity: In addition, it is important to consider the inclusiveness or exclusiveness of initiatives, based on the differentiated needs of target groups. Currently, it seems that Gardening around the Corner presents an inclusionary structure while the Free Pre-school is de facto exclusionary when it comes to certain groups (e.g. unemployed parents). The findings suggest that it is important to distinguish between top-down and bottom-up initiatives and their respective possibilities to create a sense of belonging and promote place attachment, social embeddedness and coresponsibility. Self-organised groups can sometimes be exclusionary (e.g. including mainly highly educated Austrian residents), and indeed organisers of top-down initiatives argue that the top-down nature of their initiative enables them to enforce the inclusion of non-Austrians. On the other hand, we find that bottom-up initiatives are more likely to create co-responsibility, which may also be a prerequisite for participation.

Interethnic coexistence: The currently observed, largely conflict-free interethnic coexistence seems to be maintained to a certain degree through the avoidance of deeper social contacts between ethnic communities. Many interviewees find that people and different ethnic groups live side-by-side in the local context, and many of them are already 'saturated' with contacts. However, this situation of conflict-free interethnic coexistence requires efforts to be maintained, both efforts to avoid conflict, but also 
towards creating neighbourhood attachment and co-responsibility. Possible questions for policymakers in this regard are:

- How might conflict avoidance (through contact avoidance) affect interethnic coexistence in the long-term?

- How does this apply to policy strategies, such as preventative vs. curative approaches?

- What are the medium and long-term aims of the political decision-makers in this respect?

- What role do the strategies of other dominant groups beside public authorities play (e.g. real estate developers)?

The efforts for peaceful coexistence: Peaceful coexistence is an asset that needs to be valued and promoted. The City of Vienna implements a broad package of initiatives that, together with a multitude of (supported) neighbourhood initiatives, promotes coexistence in the direct living environment, thereby promoting integration on the neighbourhood level. It is essential that the city administration and urban policies maintain mainly peaceful coexistence by continuing to take their duty to promote integration seriously. Realistically, social and ethnic mixing does not have to (and cannot) be forcibly created. Also living side-by-side without larger conflicts can have a stabilising effect on the neighbourhood. To this end, a commitment on behalf of the city is needed as well as continuous tangible support. Ideally, this strategy helps to increase residents' belonging and sense of community in a neighbourhood.

In order to promote the development of belonging and co-responsibility, we suggest several actions in different fields for policymakers in Vienna.

\section{Spaces of encounter}

Interpersonal and neighbourly coexistence takes place in public space. These interactions can - but do not have to - be characterised as interethnic. It is crucial to acknowledge the potential of public space to enable social interaction. Especially in these places, low-threshold encounters between neighbourhood residents can take place and convey a feeling of belonging. Loose, non-committal social contacts on the street and in public spaces are appreciated by most residents and have a positive effect on neighbourhood belonging.

\section{$>$ Financing and design}

Creating a space of encounter does not require large financial investments. Public space only needs functional and creative planning to function as a space 
of encounter. This includes, for example, seating areas, designated areas for ball games or dogs, or parks. The space of encounter is produced by the residents themselves by meeting and interacting with each other. Urban planning and the specifications of functional forms of use (play, rest, passing by, etc.) should be open for appropriation by different groups of users. The spectrum of forms of appropriation is unlimited and ranges from 'sitting in groups on benches' to starting a neighbourhood garden on an adjacent site.

\section{$>$ Community spaces are not yet neighbourhood spaces}

Our analysis illustrates that public space is under pressure and availability tends to decrease rather than increase. Private community spaces must be considered critical in this regard, especially in new building projects by housing cooperatives. While creating a sense of belonging within the housing community, they are separate from their direct environment. Public space can then - even if the potential were there - no longer serve as a space of encounter because these encounters take place in private community kitchens, on roof terraces, or at the swimming pool. In a growing city such as Vienna, where new building activities are increasing, it is therefore essential to create community places that are open to outsiders too. This can happen, for example, through activities and parties, but also through inclusive initiatives from the neighbourhood.

\section{$>$ Gate-Openers from the communities}

Local actors who serve as gate-openers to different ethnic groups are key to disseminating information. They act both as community members and as bridging contacts between different social groups. As a result, they enable access to hardto-reach groups on a low-threshold basis and are therefore essential mediators. The challenge lies in identifying these people, gaining their trust and becoming active together with them in the neighbourhood.

\section{$>$ Outreaching multilingualism}

The foundation of any integration process is a mutual basis of trust. Understanding integration as a bi- or multilateral process also means that society and its urban governance representatives are required to proactively address and include migrants and marginalised groups. Since these individuals often do not feel addressed by or included in existing activities and programmes, multilingual communication is a good start. The transmission of information through gatekeepers within the communities (through word-of-mouth), however, tends to have a larger effect.

\section{Low-entry barriers}

Financial and other prerequisites for participation (such as employment requirements, advanced German language skills, IT skills, etc.) in initiatives can 
result in additional entry barriers and lessen the value of these spaces as spaces of encounter. One example is the free pre-school, which requires employment of both parents in the non-compulsory pre-school years.

\section{> Bottom-up initiatives \& cooperative governance}

The financial support system for individual bottom-up initiatives in Vienna is well established. However, acquiring this individual funding requires extensive knowledge and good German language skills. It is thus essential to support hard-to-reach groups with the ethos of 'enabling instead of preventing'. It is vital to improve connections between different institutional actors and enable and promote their cooperation. For instance, diverse municipal departments responsible for an overarching topic should also cooperate in the long-term funding of bottom-up initiatives and create synergies. Furthermore, migrants and marginalised groups need to be included at the development stage of integration initiatives. The formal inclusion of hard-to-reach groups in already existing programmes, developed by the dominant Austrian middle class, is not conducive to the development of co-ownership.

\section{> Developing together: Long-term co-creation}

Initiative organisers - often private persons - need planning and funding security. To promote the sustainability of projects and related trust-building, long-term processes of co-creation between municipal decision-makers and individuals should be the aim. In doing so, a stronger impact might be achieved.

Last but not least, it should be mentioned that academic research creates momentum for political initiatives. As part of the research design, the ICEC team in Vienna attempted to create a mutual learning process between researchers, political stakeholders and local residents through the ICEC urban living labs. The collaboration with the urban renewal offices represents the interaction between academia and intermediate political actors. However, the interest shown by municipality departments and local politicians in the ICEC results has to be mentioned, as well. We learned from political decision-makers that collaboration within a research project is important and can even go beyond initially intended project aims. For example, the low-threshold community space in Herbststraße (ULL16) would not have been realised without the funding and expertise that an international research project offers. As such, research projects can provide a rationale and stimulus for implementing already existing ideas within local administrations. 


\section{Reflections from Practitioners \\ in Urban and Regional Planning in Stockholm:}

The key outcomes for the Stockholm County Council from participating in the ICEC project can be summarised in a few points that we intend to add to the policy development in our forthcoming regional development plan for the Stockholm region, RUFS 2050, and implement in our regional development work:

- Long-term cooperation is crucial: Where concrete projects at the local level can be a means to understanding social change and prevailing local conditions, projects must be initiated cautiously as there is risk of project fatigue.

- Citizens, stakeholders, practitioners \& policymakers must work together vertically and horizontally.

- Practitioners can/should interact with researchers on issues that we need to understand better but are unsure of how to address. They must also be very clear to researchers to unsure that research outcomes are also policy relevant. Practitioners should thus participate actively in formulating the research question with researchers.

- Regional/local level interaction is crucial.

- The importance of meeting places and venues is something that regional practitioner can contribute towards.

- Provide a framework for the support of local initiatives where citizens themselves decide the content.

- Need for increased flexibility within the system

- Capacity building of citizen activists

- Unconventional use of space and introducing services to participants that go beyond the expected

- In contrast to researchers who focuses on an "ethical exit" once the research is done, as a practitioner it is not really possible to 'exit' if a lasting impact is intended. The responsibilities of practitioners is about remaining to some degree, and can be achieved, for example, through:

- Transparency and feedback to partners and stakeholders

- Invest in trust by showing up occasionally and ask about how the project is progressing.

- Talk and be open about your roles, legitimacy and scope of influence that results have had or have not had. 


\section{ZUSAMMENFASSUNG:}

Die Stadt Wien betreffend gilt ebenfalls, dass das städtische Wohnumfeld vor allem für jüngere und mobilere BewohnerInnen keineswegs immer den wichtigsten räumlichen Bezugsrahmen darstellt. Es ist daher notwendig, weitere räumliche Bezugsebenen und städtische Referenzgrößen in die Formulierung eines Katalogs von Empfehlungen einzubeziehen, denn politische Entscheidungsträger können realistischerweise keine stets ",hyperaktiven“ BewohnerInnen erwarten. Wichtige Aspekte betreffen die Inklusivität versus Exklusivität bei den Initiativen, das weitgehend konfliktfreie interethnische Zusammenleben, welches in Wien in einem bestimmten Ausmaß durch die Vermeidung engerer Kontakte garantiert wird, sowie die Bemühungen um ein friedliches Nebeneinanderleben, welches von der Stadt Wien in besonderem Maß gefördert wird. Realistischerweise kann soziale und ethnische Durchmischung mittels Maßnahmen nicht erzwungen werden. Auch das Nebeneinanderherleben ohne größere Konflikte besitzt einen stabilisierenden Effekt auf die Wohnviertel. Um dieses Ziel weiterhin zu garantieren, wäre einerseits ein Bekenntnis dazu seitens der Stadt Wien förderlich, andererseits die Fortsetzung unterstützender Maßnahmen in diese Richtung. Zur Förderung und Weiterentwicklung des Zugehörigkeitsgefühls sowie der Mitverantwortlichkeit werden für die politischen Enscheidungsträger die folgenden Empfehlungen bzw. Vorschläge verbalisiert: Begegnungsräume, die auf der Förderung des Potentials des öffentlichen Raums basieren, niedrigschwellige soziale Interaktionen zu ermöglichen; Finanzierung und Design: Begegnungsräume bedürfen in der Regel keiner hohen finanziellen Investitionen, aber funktioneller und kreativer Planung; Räume für bestimmte Gruppen sind nicht immer Nachbarschaftsräume: Dies bedeutet, dass die Verfügbarkeit des öffentlichen Raums abnimmt, da in Neubauprojekten die Nutzung bestimmter Teilräume nicht selten den BewohnerInnen vorbehalten bleibt; Gate-opener in den Communities, denn diese garantieren den Zugang zu schwer erreichbaren Gruppen; weitreichende Multilingualität und niedrige Zutrittsbarrieren, die Einbindung von Bottom-up-Initiativen in kooperative Governance-Strukturen und langfristige Prozesse der Kokreation.

\section{SAMENVATTING:}

In Wenen is de stedelijke woonomgeving, in het bijzonder de buurt, zeker niet altijd het primaire referentiekader. Met name voor jongere en meer mobiele bewoners heeft de buurt niet noodzakelijkerwijs een grote betekenis, en er kan dan ook niet worden verwacht dat alle bewoners actief zullen worden in de buurt. Wat betreft bestaande initiatieven blijft het van belang om in de gaten te houden in hoeverre hun organisatie (onbedoeld) leidt tot uitsluiting van bepaalde groepen. Meer in het algemeen kan worden gesteld dat de huidige situatie van relatief vreedzaam interetnisch samenleven vooral in stand wordt gehouden doordat groepen naast elkaar leven en niet per se intensievere contacten zoeken. Desalniettemin blijft het een belangrijke taak voor de lokale overheid om ervoor te zorgen dat dit niet omslaat in een situatie van verwaarlozing 
en spanningen. Enkele meer specifieke aanbevelingen voor de Weense context zijn: het erkennen van de kracht van publieke ruimtes als mogelijke ontmoetingsplaatsen voor verschillende groepen, zorgen voor functionele en creatieve stedenbouwkundige ontwerpen die contact stimuleren, garanderen dat naast het groeiende aantal semipublieke of private gemeenschapsruimtes er ook publieke ruimtes blijven bestaan die voor iedereen toegankelijk zijn, contacten onderhouden met gatekeepers uit gesloten en lastig te bereiken gemeenschappen, communicatie in meerdere talen, het wegnemen van bestaande barrières voor participatie en het ondersteunen van bottom-up initiatieven en samenwerkingen tussen officiële instanties en migrantenorganisaties. 